\title{
Synthesis, Identification and Anti-Cancer Activity of 1-(4-Methylpent-2-enyl)-2-(4-phenylbut-2-enyl)disulfane
}

\author{
Chunxiao $\mathrm{Ji}^{1}$, Fenglian Ren ${ }^{1, *}$ and Ming $\mathrm{Xu}^{2}$ \\ 1 College of Chemistry and Chemical Engineering, Central South University, Changsha, Hunan \\ 410083, China; E-Mail: cx312@163.com (C.J.) \\ 2 Research Institute for Molecular Pharmacology and Therapeutics, Central South University, \\ Changsha, Hunan 410083, China
}

* Author to whom correspondence should be addressed; E-Mail: renfl2009@yahoo.com.cn.

Received: 8 July 2010; in revised form: 5 August 2010 / Accepted: 9 August 2010 /

Published: 16 August 2010

\begin{abstract}
In this study, we synthesized 1-(4-methylpent-2-enyl)-2-(4-phenylbut-2enyl)disulfane using sodium sulfide, 1-bromine-4-methyl-2-amylene and 1-(4-bromine-2butylene)benzene as raw materials. The yield rate of target product was $84 \%$. The structure of the target product was confirmed by GC-MS, ${ }^{1} \mathrm{H}-\mathrm{NMR}$ and elemental analysis. The results of anti-cancer activity experiments showed that 1-(4-methylpent-2-enyl)-2-(4phenylbut-2-enyl)disulfane could significantly inhibit the proliferation, induce the apoptosis of CNE2 cells in a dose dependent manner, and could significantly enhance the activity of XIAP.
\end{abstract}

Keywords: 1-(4-methylpent-2-enyl)-2-(4-phenylbut-2-enyl)disulfane; synthesis; anti-cancer activity; XIAP

\section{Introduction}

Allicin is a natural allyl sulfide and one of the various sulfur compounds extracted from garlic, along with diallyl trisulfides, diallyl disulfides and so on [1-5]. Since 1980, allicin has attracted more and more attention because of its potential cancer prevention and anti-cancer effects [6]. At present, studies have shown that DADS (diallyl disulfide), a possible precursor of allicin, is a drug with broad-spectrum anti-cancer effects. It can inhibit the growth of various tumor cells, such as human colon cancer cells (HCT-15), human skin cancer cells (SK MEL-2), human gastric cancer cells, human 
breast cancer cells (MCF-7, KPL-1), and so on [7-12]. Certainly, study on the bioactivity of other sulfur compounds in this area continues.

NPC (nasopharyngeal carcinoma) is a kind of malignant tumor with high incidence in the Southeast Asia region. In the clinic, NPC therapy is usually based on radiation treatments, but the therapeutic effects are not satisfactory. In recent years, a lot of researchers have focused on investigating the anti-cancer mechanisms of active ingredients extracted from natural plants to prevent and treat cancer [13-15]. In this context, however, allicin, the main active ingredient of garlic, is unstable, and decomposes very easily during the extraction process. 1,2-bis(2-Methylallyl)disulfane (Figure 1) is a sulfur compound related to allicin with various biological activities [16-18]. Our previous work has demonstrated that 1,2-bis(2-methylallyl)disulfane could significantly inhibit the proliferation, and induce the apoptosis of human HepG2 cells. In this paper, we have successfully synthesized 1-(4-methylpent-2-enyl)-2-(4-phenylbut-2-enyl)disulfane using sodium sulfide, 1-bromine-4-methyl-2amylene and 1-(4-bromine-2- butylene)benzene as raw materials, connecting isopropyl and benzyl groups to both ends of 1,2-bis(methylallyl)disulfane, and proved that the resulting 1-(4-methylpent-2-enyl)-2-(4-phenylbut-2-enyl)disulfane could significantly inhibit the proliferation and induce apoptosis.

Figure 1. Structure of 1,2-bis(methylallyl)disulfane.

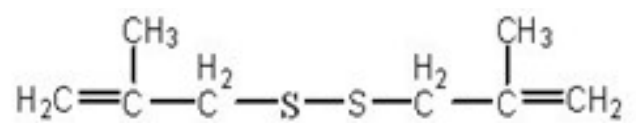

\section{Results and Discussion}

The synthetic route used is shown in Scheme 1. The target 1-(4-methylpent-2-enyl)-2-(4-phenylbut-2-enyl)-disulfane was obtained as yellow oily substance in $84.0 \%$ yield and purity above $99 \%$.

Scheme 1. Synthesis route to 1-(4-methylpent-2-enyl)-2-(4-phenyl- but-2-enyl)-disulfane.

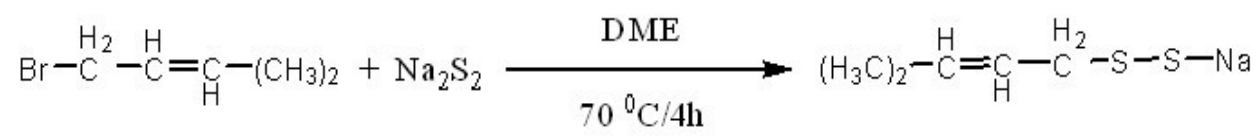

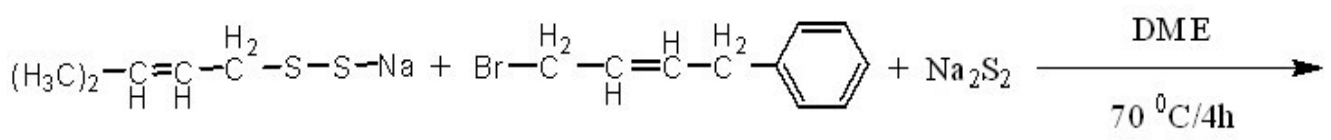

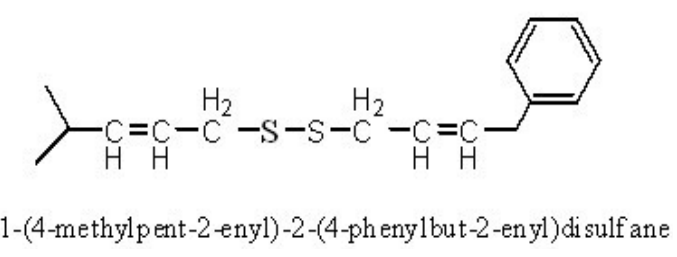

In order to investigate the apoptosis effects on the CNE2 nasopharyngeal cancer cell line induced by 1-(4-methylpent-2-enyl)-2-(4-phenylbut-2-enyl)disulfane and its molecular mechanisms, the growth 
inhibition and apoptosis of CNE2 cells and the protein levels of XIAP were examined by MTT assay, flow cytometry and Western blot, respectively.

To test the effect of 1-(4-methylpent-2-enyl)-2-(4-phenylbut-2-enyl)disulfane on CNE2 cells, cell viability was determined by the MTT assay. As shown in Figure 2, the CNE2 cells were exposed to drug concentrations of $0,50,100$ and $150 \mu \mathrm{mol} / \mathrm{L}$ for $24 \mathrm{~h}$, and the results showed that the inhibition ratios of treated with $50 \mu \mathrm{mol} / \mathrm{L}, 100 \mu \mathrm{mol} / \mathrm{L}$ and $150 \mu \mathrm{mol} / \mathrm{L}$ 1-(4-methylpent-2-enyl)-2-(4-phenylbut-2-enyl)disulfane were $16.03 \%, 29.51 \%$ and $49.47 \%$, respectively and the inhibition was evidently dose dependent.

Figure 2. Results of the MTT assay.

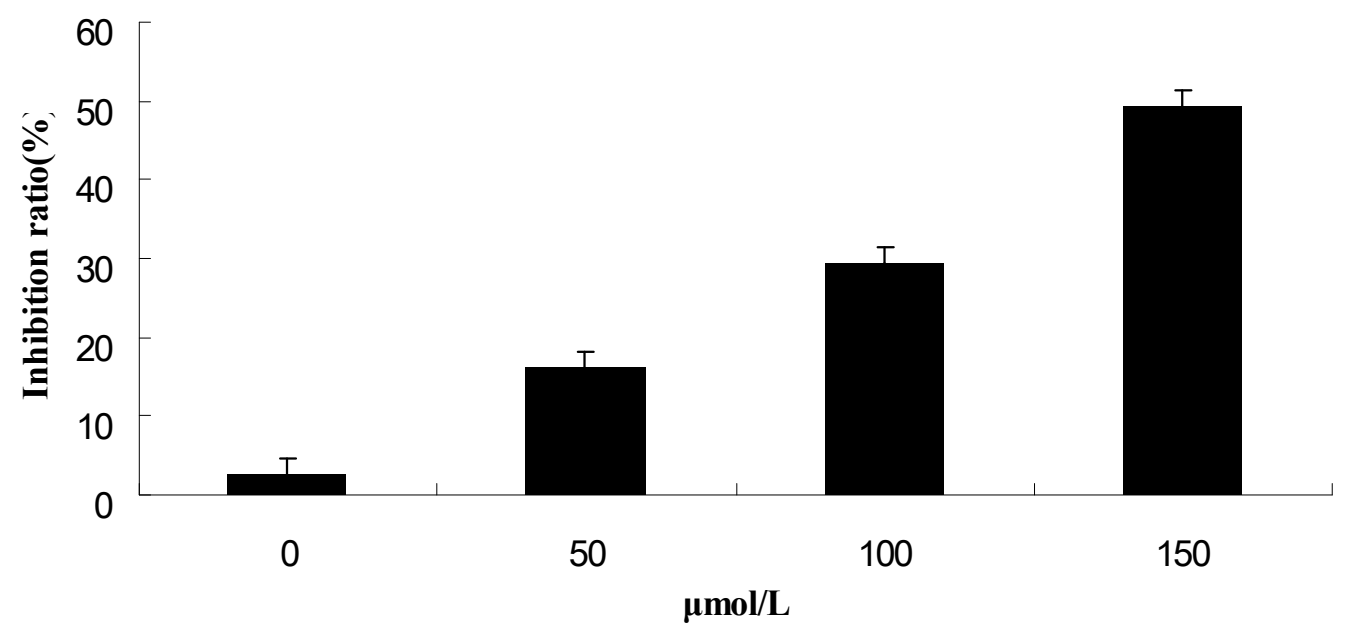

Results are representative of three replicates $(\mathrm{P}<0.01)$.

To further examine the effects of 1-(4-methylpent-2-enyl)-2-(4-phenylbut-2-enyl) disulfane on apoptosis, flow cytometry was used to quantify the apoptotic state (Figure 3 and Figure 4).

Figure 3. Effects of each group on apoptosis in in CNE2 cells.
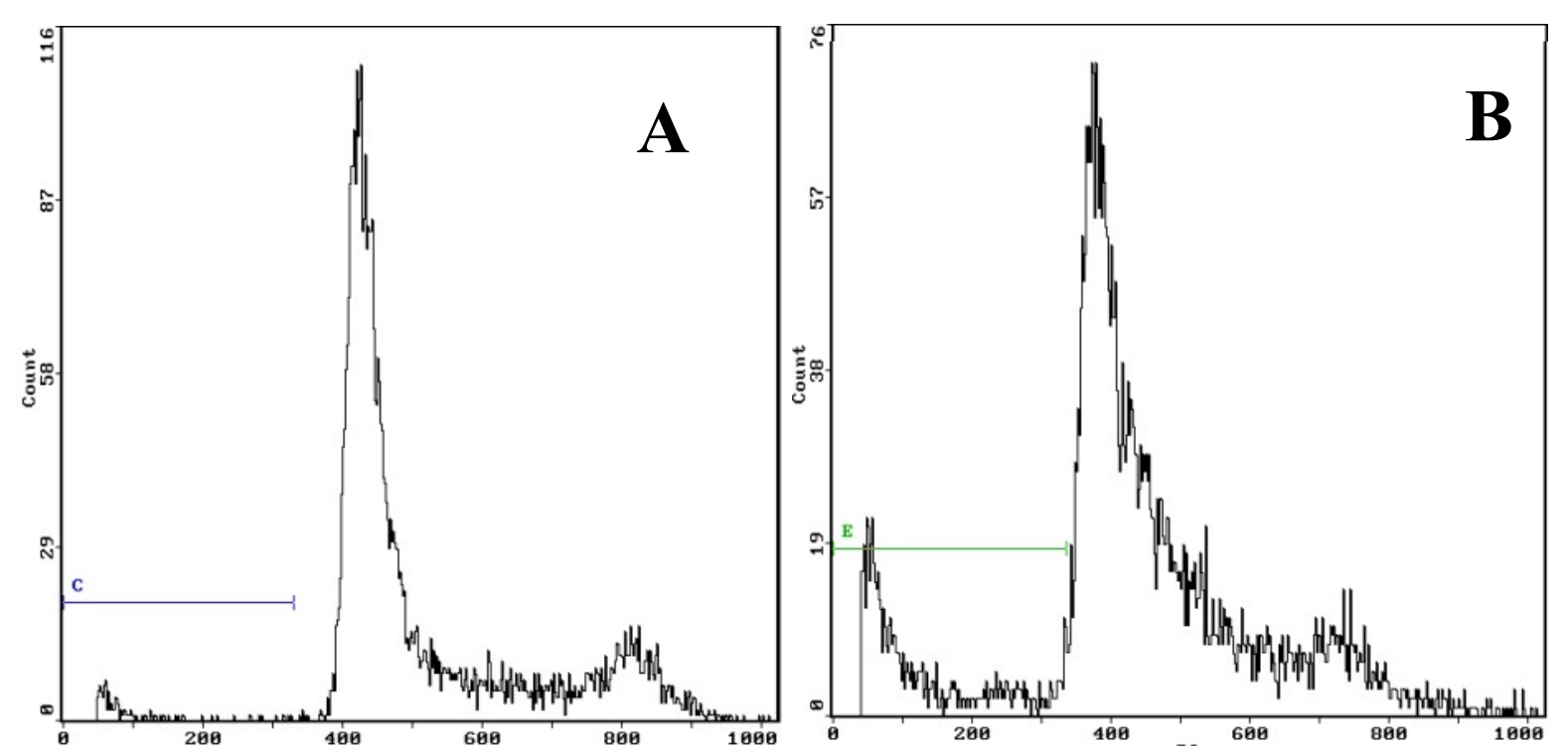
Figure 3. Cont.
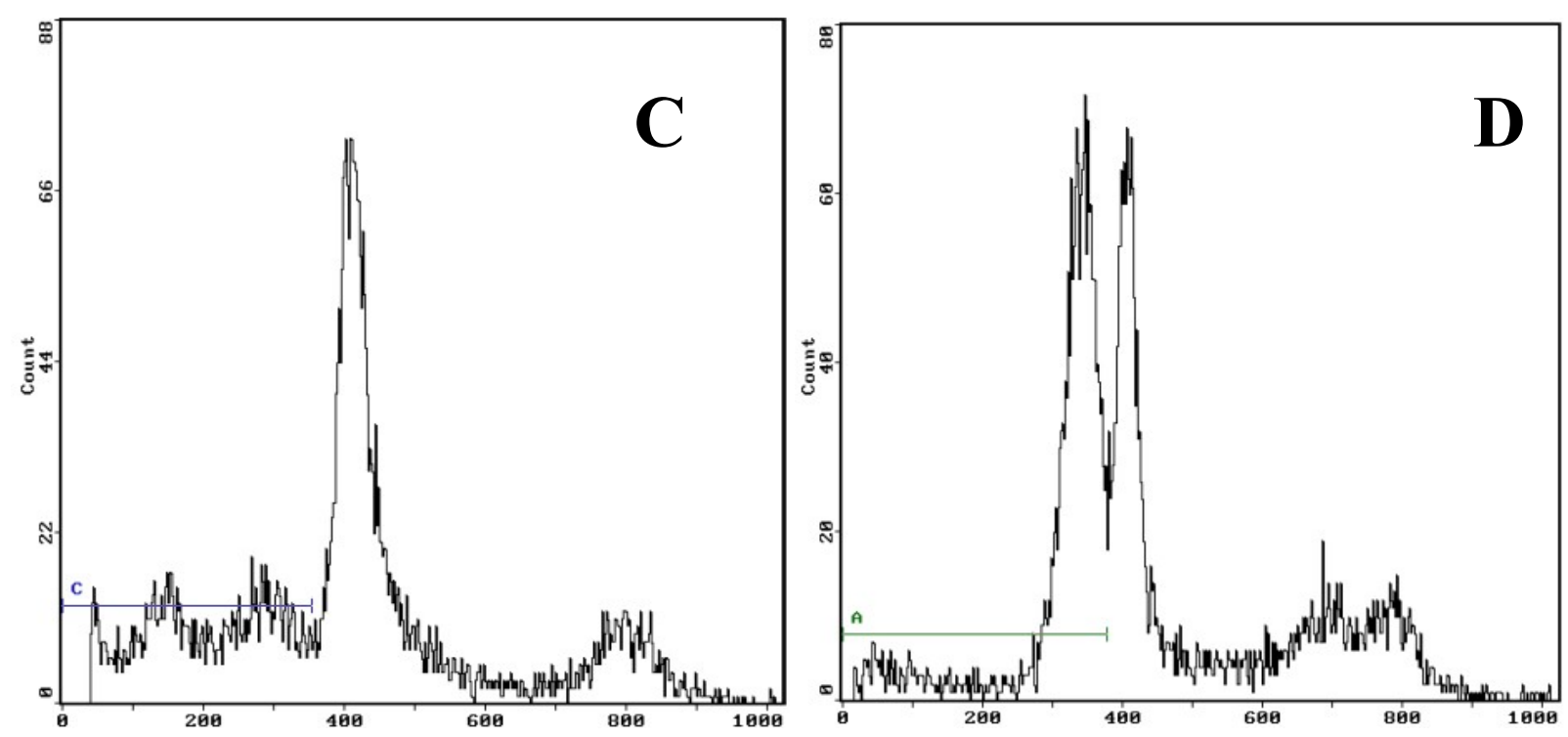

A. Control (untreated); B. 1-(4-methylpent-2-enyl)-2-(4-phenylbut-2-enyl)disulfane (50 $\mu \mathrm{mol} / \mathrm{L})$; C. 1-(4-methylpent-2-enyl)-2-(4-phenylbut-2-enyl)disulfane (100 $\mu \mathrm{mol} / \mathrm{L}) ; \quad$ D. 1-(4-methylpent-2enyl)-2-(4-phenylbut-2-enyl)disulfane $(150 \mu \mathrm{mol} / \mathrm{L})$; Results are representative of three replicates.

Figure 4. Results of the flow cytometry analysis.

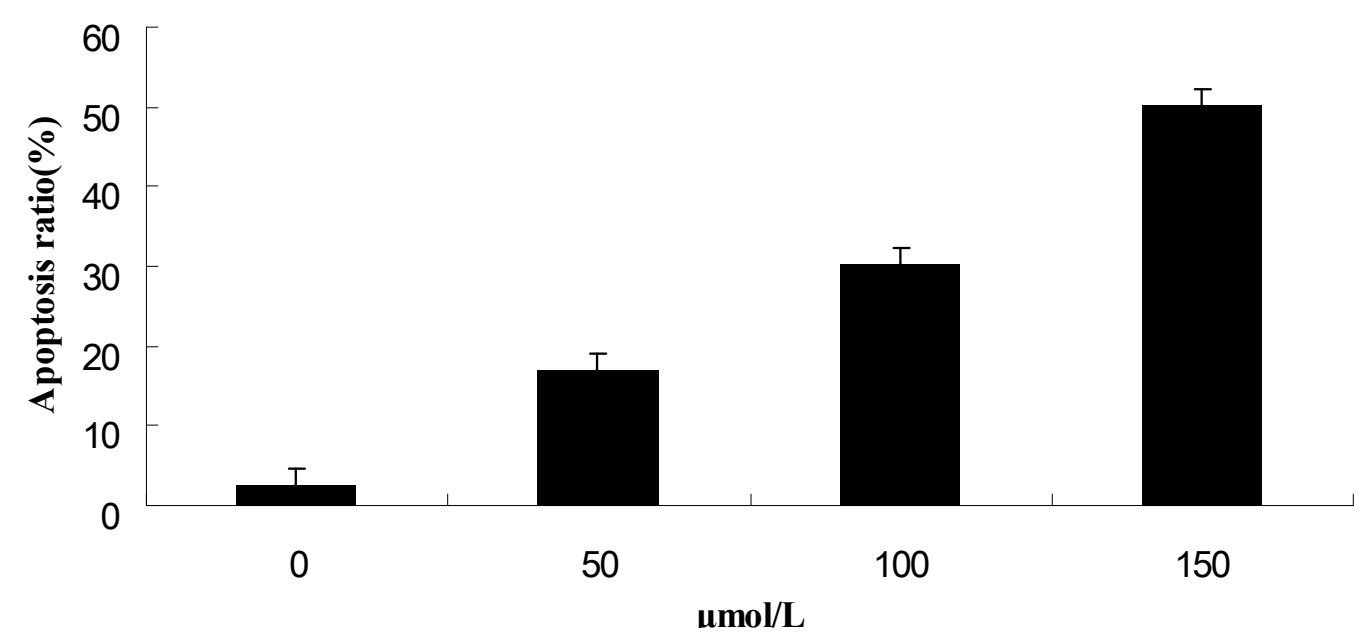

Results are representative of three replicates $(\mathrm{P}<0.01)$.

After treatment and incubation for $24 \mathrm{hr}$, the apoptosis ratios of cells treated with 50, 100 and $150 \mu \mathrm{mol} / \mathrm{L}$ 1-(4-methylpent-2-enyl)-2-(4-phenylbut-2-enyl) disulfane were $16.97 \%, 30.27 \%$ and $50.32 \%$, respectively. The results also supported the notion that 1-(4-methylpent-2-enyl)-2-(4-phenylbut2-enyl)disulfane induced apoptosis of CNE2 cells in a concentration-dependent manner.

XIAP (X-linked inhibitor of apoptosis protein) is an important member of the IAPS (inhibitor of apoptosis protein) family. To test the effect on XIAP when 1-(4-methylpent-2-enyl)-2-(4-phenylbut-2enyl)-disulfane induced apoptosis of human CNE2 cells, we examined XIAP protein expression by Western blot analysis. After treatment with 1-(4-methylpent-2-enyl)-2-(4-phenylbut-2-enyl)disulfane $(50,100,150 \mu \mathrm{mol} / \mathrm{L}$, respectively) for $24 \mathrm{~h}$, the expression of XIAP was significantly increased. When the concentration of 1-(4-methylpent-2-enyl)-2-(4-phenylbut-2-enyl)disulfane was increased, 
the expression protein of XIAP was also increased gradually (Figure 5), and our results showed that the activity of XIAP was enhanced significantly by the treatment.

Figure 5. Effects of 1-(4-methylpent-2-enyl)-2-(4-phenylbut-2-enyl)disulfane on the protein expressions by Western blot.

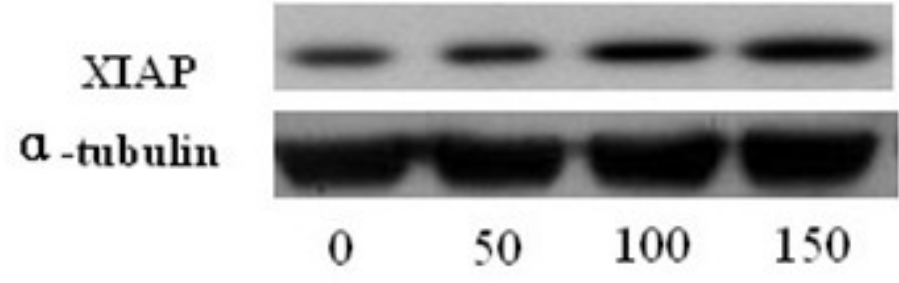

\section{$\square$ a-tubulin $\square$ XIAP}

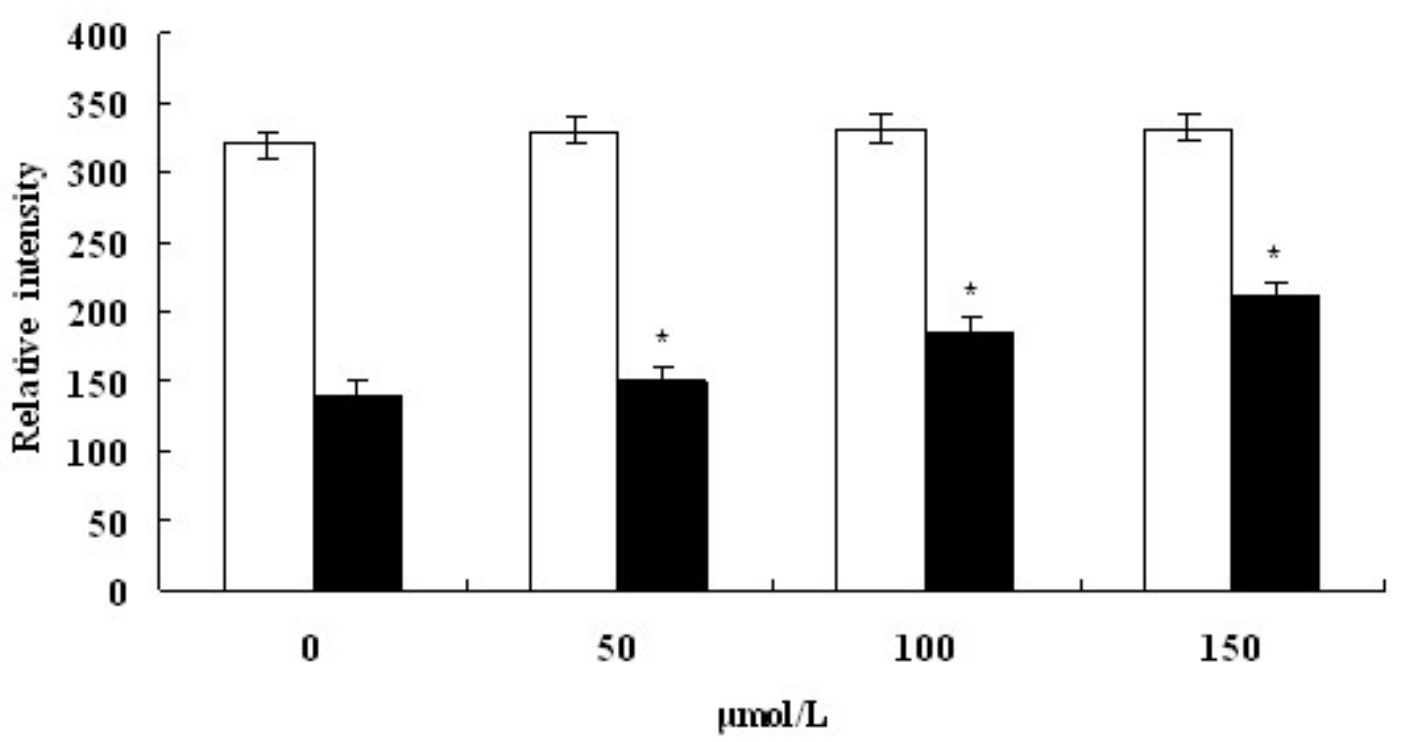

Results are representative of three replicates $(\mathrm{P}<0.05)$

\section{Experimental}

\subsection{General}

3-Chloro-2-methylpropylene, 1-bromo-4-methyl-2-amylene, 1-(4-bromine-2-butylene)benzene and 1,2-dimethoxyethane (DME) were purchased from Fluka. Ether, benzophenone, sulphur, chloroform and carbinol were purchaed from Nanjing Chemical Reagents Co. 3-(4,5-Dimethylthiazol-2-yl)-2,5-diphenyltetrazolium bromide (MTT) and propidium iodide (PI) were purchased from Sigma. XIAP and $\alpha$-tubulin were purchased from Cell Signaling. DME was dried with metal sodium using benzophenone as the indicator before being used. ${ }^{1} \mathrm{H}-\mathrm{NMR}$ was recorded on a Bruker DRX-500 spectrometer at $298 \mathrm{~K}$, elementary analysis was performed on a Perkin-Elmer $240 \mathrm{C}$ analytic instrument. GC-MS analyses were performed on a HP6890 gas chromatograph equipped with a HP 5973 mass selective detector (MS) and a fused-silica-capillary column, DB-5, (30 m × 0.32 mm). 


\subsection{Synthesis of 1-(4-methylpent-2-enyl)-2-(4-phenylbut-2-enyl)disulfane}

Sodium metal sheet $(12.7 \mathrm{~g}, 0.55 \mathrm{~mol})$ was added to DME $(100 \mathrm{~mL})$ with fast stirring, and then sulphur powder $(16.0 \mathrm{~g}, 0.50 \mathrm{~mol})$ was added after the sodium metal was completely dispersed, and stirring of the mixture was continued at the room temperature for $2 \mathrm{~h}$, to give the product $\mathrm{Na}_{2} \mathrm{~S}_{2}$, which was sealed and kept in a cool place [19-21]. $\mathrm{Na}_{2} \mathrm{~S}_{2}(50 \mathrm{~mL})$ was transferred into a round bottom flask $(250 \mathrm{~mL})$, then DME $(50 \mathrm{~mL})$ which contained 1-bromo-4-methyl-2-amylene (40.8 g, $0.25 \mathrm{~mol})$ was added dropwise into the round bottom flask with continuous stirring, and then reacted in a $70{ }^{\circ} \mathrm{C}$ oil bath for $4 \mathrm{~h}$. After that, solvent was removed by the rotary evaporator under vacuum, and a bright yellow oily matter was thus obtained. The oily matter was added into distilled water $(50 \mathrm{~mL})$ and dispersed with ultrasound, then extracted with ether $(20 \mathrm{~mL})$ five times, and extracted with chloroform three times. The combined extracts was evaporated under vacuum to remove the solvent. The product was finally purified by silica gel column chromatography, using chloroform/methanol $(\mathrm{v} / \mathrm{v}=99 / 1)$ as mobile phase [22].

\subsection{Characterization of 1-(4-methylpent-2-enyl)-2-(4-phenylbut-2-enyl)disulfane}

${ }^{1} \mathrm{H}-\mathrm{NMR}:\left(\mathrm{CDCl}_{3}\right) \delta$ (ppm): 7.04-7.02 (2H, d, 3,5-Ph-H), 6.91-6.81 (3H, t, 2,4,6-Ph-H), 6.79-6.79 $\left(1 \mathrm{H}, \mathrm{t}\right.$, benzyl-CH=), 5.56-5.47 $(3 \mathrm{H}, \mathrm{t},-\mathrm{CH}=\mathrm{CH}-+$ benzyl-CH= $\mathrm{CH}-), 3.19-3.16\left(6 \mathrm{H}, \mathrm{t},-\mathrm{CH}_{2}-\right)$, 2.22-2.19 (1H,d, (CH3) $\left.)_{2} \mathrm{CH}-\right), 1.33\left(6 \mathrm{H}, \mathrm{s},-\mathrm{CH}_{3}\right) \mathrm{ppm}$; Elemental analysis: found (calcd.) (\%): $\mathrm{C}$, 68.89 (69.01); H, 7.92 (7.96); S, 23.14 (23.03); GC-MS analysis (m/z): $278\left(\mathrm{M}^{+}\right), 163,147,138,131$, $115,109,104,99,95,94,91,83,72,69,55,44,40$.

\subsection{Cell culture}

CNE2, a human nasopharynaeal carcinoma cell line, were cultured in RPMI1640 with 10\% heat-inactivated fetal bovine serum (FBS), benzylpenicillin (100 kU/L) and streptomycin (100 mg/L) at $37{ }^{\circ} \mathrm{C}$ in an incubator containing humidified air with $5 \% \mathrm{CO}_{2}$.

\subsection{Cell viability assay}

To assess the cytotoxic effects of DADS in CNE2 cells, we used a3-(4,5-dimethylthiazol-2-yl)-2,5diphenyltetrazolium bromide (MTT) tetrazolium salt reduction assay [23]. In this assay, the MTT is used as a colorimetric substrate for measuring cell viability. When cells are injured, there is an alteration in the cellular redox activity such that cells are unable to reduce the dye [7]. Cells were seeded into 96-well plates at $1 \times 10^{4}$ cells per well $24 \mathrm{~h}$ before treatment. The cultures were then rinsed in phenol-free RPMI1640 medium and incubated with respective test substances in phenol-free and serum-free RPMI1640 for $24 \mathrm{~h}$. In the inhibition test, cells were treated with 1-(4-methylpent-2-enyl)-2-(4-phenylbut-2-enyl) disulfane. At the end of this time interval, $20 \mu \mathrm{L}$ $(5 \mathrm{mg} / \mathrm{mL})$ MTT was added to each well, and after incubation at $37{ }^{\circ} \mathrm{C}$ for $4 \mathrm{~h}$, the MTT solution was removed and $200 \mu \mathrm{L}$ of dimethylsulfoxide (DMSO) was added to dissolve the crystals. The absorbance of each well was measured at $570 \mathrm{~nm}$. 


\subsection{Flow cytometry analysis}

Cells were seeded into $100 \mathrm{~mL}$ cell culture bottles at $12 \times 10^{6}$ cells $24 \mathrm{~h}$ before treatment. Then cells were treated according to the aforementioned method and incubated for $24 \mathrm{~h}$. Afterwards, floating and adherent cells were collected, washed three times with PBS ( $\mathrm{pH} 7.4)$ and fixed for $24 \mathrm{~h}$ with cool alcohol at $4{ }^{\circ} \mathrm{C}$. $1 \mathrm{~mL}$ cell suspension $\left(10^{6} / \mathrm{mL}\right)$ was washed three times with cooled PBS, treated with RNase for $30 \mathrm{~min}$ at $37^{\circ} \mathrm{C}$, stained it with PI for $30 \mathrm{~min}$ at $37^{\circ} \mathrm{C}$ in a dark environment, and taken for flow cytometry analysis.

\subsection{Western blotting}

The cells were taken in the logarithmic growth phase, treated according to the aforementioned method and incubated for $24 \mathrm{~h}$. After fragmentation on ice for $20 \mathrm{~min}$, the lysates were centrifuged at $15,000 \times \mathrm{g}$ for $10 \mathrm{~min}$ at $4{ }^{\circ} \mathrm{C}$, the protein was collected, quantitated with the BCA method, electrophoresed and isolated by the SDS-PAGE (10\%) using the electrotransfer method, blocked and hybridized on the cellulose nitrate film. Then the protein expression of cells was detected using the ECL Western blotting method. The densities of protein bands were calculated using the Quantity One software.

\subsection{Statistics}

Data are expressed as mean \pm S.D of three independent experiments and were evaluated by one-way analysis of variance (ANOVA). Significant differences were established at $\mathrm{P}<0.05$.

\section{Conclusion}

The target product 1-(4-methylpent-2-enyl)-2-(4-phenylbut-2-enyl)disulfane was characterized by GC-MS, ${ }^{1} \mathrm{H}-\mathrm{NMR}$ and elemental analysis. The results of anti-cancer activity experiment showed that this compound could significantly inhibit the proliferation of CNE2 cells, induce apoptosis in a dose dependent manner, and could significantly enhance the activity of XIAP.

\section{References}

1. Sundaram, S.G.; Milner, J.A. Diallyl disulfide induces apoptosis of human colon tumor cells. Carcinogenesis 1996, 17, 669-673.

2. Kwon, K.B.; Yoo, S.J.; Ryu, D.G.; Yang, J.Y.; Rho, H.W.; Kim, J.S. Induction ofapoptosis by diallyl disulfide through activation of Caspase-3 in human leukemia HL-60 cells. Biochem. Pharmacol. 2002, 63, 41-47.

3. Nakagawa, H.; Tsuta, K.; Kiuchi, K.; Senzaki, H.; Tanaka, K.; Hioki, K. Growth inhibitory effects of diallyl disfulfide on human breast cancer cell lines. Carcinogenesis 2001, 22, 891-897.

4. Bottone, F.G., Jr.; Baek, S.J.; Nixon, J.B.; Eling, T.E. Diallyl disulfide (DADS) induces the antitumorigenic NSAID-activated gene (NAG-1) by a p53 dependent mechanism in human colorectal HCT 116 cells. J. Nutr. 2002, 132, 773-778. 
5. Druesne-Pecollo, N.; Pagniez, A.; Thomas, M.; Cherbuy, C.; Duee, P.H.; Martel, P.; Chaumontet, C. Diallyl Disulfide Increases CDKN1A Promoter-Associated Histone Acetylation in Human Colon Tumor Cell Lines. Agric. Food Chem. 2006, 54, 7503-7507.

6. Sundaram S.G.; Milner J.A. Diallyl disulfide inhibits the proliferation of human tumor cells in culture. Biochim. Biophys. Acta 1996, 1315, 15-20.

7. Wen, J.; Zhang, Y.W.; Chen, X.Q.; Shen, L.B.; Li, G.C.; Xu, M. Enhancement of diallyl disulfide-induced apoptosis by inhibitors of MAPKs in human HepG2 hepatoma cells. Biochem. Pharmacol. 2004, 68, 323-331.

8. Park E.K.; Kwon K.B.; Park, K.I.; Park B.H.; Jhee E.C. Role of $\mathrm{Ca}^{2+}$ in dially1 disulfide-induced apoptotic cell death of HCT-15 cells. Exp. Mol. Med. 2002, 34, 250-257.

9. Hong, Y.S.; Ham, Y.A.; Choi, J.H.; Kim, J. Effects of ally sulfur compounds and garlic extract on expressions of Bcl-2, Bax, and p53 in nonsmall cell lung cancer cell lines. Exp. Mol. Med. 2000, 32, 127-134.

10. Xiao D.; Choi, S.; Johnson, D.E. Diallyl trisulfide - induced apoptosis in human prostate cancer cells is mediated by activation of c-Jun N-terminal kinase and extracellular-signal regulated kinase mediated phosphoryl ation of Bcl-2. Oncogene 2004, 23, 5594-5606.

11. Tsai, C.W.; Chen, H.W.; Yang, J.J.; Sheen, L.Y.; Lii, C.K. Diallyl Disulfide and Diallyl Trisulfide Up-Regulate the Expression of the $\pi$ Class of Glutathione S-Transferase via an AP-1-Dependent Pathway. Agric. Food Chem. 2007, 55, 1019-1026.

12. Nabekura T; Kamiyama, S; Kitagawa, S. Effects of dietary chemopre2 ventive phytochemicals on P-glycoprotein function. Biochem. Biophys. Res. Commun. 2005, 327, 866-870.

13. Kern, M.; Pahlke, G.; Balavenkatraman, K.K.; Bohmer, F.D.; Marko, D. Apple Polyphenols Affect Protein Kinase C Activity and the Onset of Apoptosis in Human Colon Carcinoma Cells. Agric. Food Chem. 2007, 55, 4999-5006.

14. Yoon, H.; Liu, R.H. Effect of Selected Phytochemicals and Apple Extracts on NF-кB Activation in Human Breast Cancer MCF-7 Cells. Agric. Food Chem. 2007, 55, 3167-3173.

15. Dorant, E.; Van den Brandi, P.A.; Goldbohm, R.A.; Hermus R.J.; Sturmans F. Garlic and its significance for the prevention of cancer in humans. Br. J. Cancer 1993, 67, 424-429.

16. Knowles, L.M.; Milner, J.A. Possible mechanism by which allyl sulfides suppress neoplastic cell proliferation. Nutrition 2001, 131, 1061-1066.

17. Milner, J.A. A historical perspective on garlic and cancer. Nutrition 2001, 131, 1027-1031.

18. Zhang, E.J.; Ng, K.M.; Luo, K.Q. Extraction and Purification of Isoflavones from Soybeans and Characterization of Their Estrogenic Activities. Agric. Food Chem. 2007, 55, 6940-6950.

19. Takata, T.; Saeki, D.; Makita, Y.; Yamada, N.; Kihara, N. Aromatic Hydrocarbon-Catalyzed Direct Reaction of Sulfur and Sodium in a Heterogeneous System: Selective and Facile Synthesis of Sodium Monosulfide and Disulfide. Inorg. Chem. 2003, 42, 3712-3714.

20. Roman, K.; Jan, V. Sulfur-containing volatiles arising by thermal degradation of alliin and deoxyalliin. J. Agr. Food Chem. 1997, 45, 3580-3585.

21. Gedye, R; Smith, F.; Westaway, K.; Ali, H.; Baldisera, L.; Laberge, L.; Rousell, J. The use ofmicrowave ovens for rapid organic synthesis. Tetrahedron Lett. 1986, 27, 279-282.

22. Gerard, M.; Michael, F. Organoleptic characteristics of flavor materials. Perfumer \& Flavorist 1992, $17,41-42$. 
23. Hansen, M.B.; Nielsen, S.E.; Berg, K. Re-examination and further development of a precise and rapid dye method for measuring cell grewth/cell kill. Immunol. Meth. 1989, 119, 203-210.

Sample Availability: Contact the authors.

(C) 2010 by the authors; licensee MDPI, Basel, Switzerland. This article is an Open Access article distributed under the terms and conditions of the Creative Commons Attribution license (http://creativecommons.org/licenses/by/3.0/). 